\title{
Audio Media in the Service of the Totalitarian State?
}

\author{
DMITRI ZAKHARINE
}

\section{State Totalitarianism or Media Totalitarianism?}

The question concerning the logical relationship between the structures and media of totalitarianism has been treated controversially in contemporary scholarship. A large part of the relevant publications (represented by Hannah Arendt and Leonard Schapiro $)^{1}$ defines totalitarian power primarily as the power of a charismatic leader over the unwilling majority and, following Aristotle's concept of tyranny, sees the latter as rooted in structures of political order. ${ }^{2}$ A second corpus of research increasingly interprets totalitarianism as technological power and associates

1| See: Hannah Arendt (1951: 465): "[...] totalitarian government in its initial stages must behave like a tyranny and raze the boundaries of man-made law". See: Leonard Schapiro (1972: 118): "Totalitarianism is a new form of dictatorship which grew up in the conditions of mass democracy after the First World war. It was characterized by the predominance of the leader of the victorious movement, who with the aid of his subordinate elite and a manipulated ideology aimed at total control over state, society and the individual". Peter Burke indicated certain similarities between leaders of totalitarian regimes (in the twentieth century) and absolutist regimes (in the seventeenth century) in The Fabrication of Louis XIV (Burke 1992: 203): "The contrast between $17^{\text {th }}$-century leaders and $20^{\text {th }}$-century ones is not a contrast between rhetoric and truth. It is a contrast between two styles of rhetoric". See: Gleason (1995: 7): "Although the term totalitarianism has been widely used outside the academic community and has wide currency today, one seldom sees it any longer used analytically in the pages of a scholarly monograph or journal".

2 | "Any monarchy must necessarily be a tyranny of this sort if it is rules in unchallenged fashion over persons who are similar or better and with a view to its own advantage and not that of the ruled. Hence [it is rule over persons who are] unwilling; for no free person would willingly tolerate this sort of rule" (Aristotle 1984: 4-10-1295ff). 
it with scientific inventions in the field of telecommunications. In this second corpus, the radio, the loudspeaker and sound film, i.e. media forms that realize the principle of optical sound recording, are assigned a structuralizing function with regard to the reproduction and continuity of totalitarian power.

Established trends in philosophical anthropology and the philosophy of media seem convinced that acoustic and audiovisual media have a particular affinity for exercising political power. One of their main arguments holds that humans have two eyelids, but no "earlids". Since man cannot evade auditory impact, the source of totalitarian power is said to inhere in the involuntary acoustic guidance of attention. As early as in the nineteenth-century discourses of Zivilisationskritik, hearing was treated as a sense of extreme passibility and at the same time as a guarantor of authentic perception. For indigenous peoples, auditory sensations are supposed to have been action-guiding to a greater degree than visual sensations. Based on this theory, Nietzsche attempted to derive the meaning of Greek tragedy from the spirit of music in 1872. At around the same time, the sociologist Georg Simmel (1882) noted "that in all primitive peoples [...] music [...] plays a key role”. Cultural historian Egon Friedell (1949) later maintained that "the receptivity and sensitivity of the Greeks to the power of sound [was] downright pathological". While it is no longer desired to reflect on the finer differences between the universals of acoustic perception and socially constructed listening contexts, contemporary cultural studies has by and large subscribed to the above-mentioned theories of philosophy and philosophical anthropology. 3

In the 1960s, media studies pioneer Marshall McLuhan established the "monopolistic effect" of the radio by bringing concepts such as "auditory space" and Lebensraum into a close relationship with one another. ${ }^{4}$ In McLuhan's work, the famous analogy between the radio and the tribal drum applies first and foremost to the public listening cultures of developing nations. While England and America were supposedly "immune" to the radio "due to the influence of alphabetic writing and industrialization", the radio embodied "an archaic force [...] for the peoples of Africa, India, China and Russia". In these places, the radio "evoked archaic tribal ghosts of the most vigorous sort" and returned the fragmented individ-

3 | See: Welsch (1993: 99): "It follows that we are especially in need of protection acoustically".

4 | See: McLuhan (1964: 298): "It is the top item on radio, showering us with fountains of auditory space or lebensraum". 
ual to the cradle of the collective environment of voices (McLuhan 1968: 340-345).

The tradition of the concept of media totalitarianism elaborated in McLuhan's writings has produced a number of recent studies on acoustic communication. These treat the "new media" (but above all electroacoustic media) as "hot" in terms of their high potential for effecting integration. Thus Cornelia Epping-Jäger, for instance, views the loudspeaker as the source of "a medially configured vocal power". Using the term "Loud/Speaker dispositif", she analyzes the consolidation process of the technical parameters of acoustic media and the power claims of political elites. Through her analysis of Hitler's self-portrayals, Epping-Jäger arrives at the conclusion that the Loud/Speaker dispositif generated the "phonocentrism of National Socialist political communication" and promoted the internalization of power as an acoustic form of experience of the Volksgemeinschaft. ${ }^{5}$

Unlike Epping-Jäger, Inge Marszolek shows that the communal reception of both radio and loudspeaker voices would have been destined to fail without the cooperation of both listeners and producers of sound. Implanted in private rooms, the radio eluded total control: it could be switched on and off. One could avoid the infiltration of totalitarian vocal power into private spaces through the self-guided adjustment of volume. As numerous memoirs from the time of National Socialism document, this option was often exercised. The Volksempfänger was instantly silenced "as soon as a loud voice resounded from it" (Marszolek 2005: 67). For this reason, political speeches were reduced in favor of entertainment programs by 1935. According to Marszolek, mass presentations with a powerful acoustic component increasingly lost their prominence after 1935 and were reserved for only a few major National Socialist events (Marszolek 2005: 63).

It is always popular and, with certain reservations, even sensible to express alarm about the power produced by innovative technological solutions. However, scholarship has thus far failed to provide an empirical basis for equating concepts such as acoustics and totalitarianism. But the argument for the totality of the radio or the loudspeaker is valid only if it can be proven that both listeners and those who let listen use

5 | The public spaces in which the parades of the Nazis took place were organized so that none of the audience members were more than 75 meters away from a loudspeaker. Hitler's voice was amplified 50,000 volt, so that it could dominate the space of 500,000 square meters on Berlin's Tempelhof Field (Epping-Jäger 2003: 100; Epping-Jäger 2006, 166). 
and interpret these media in a certain culturally coded manner. This requires greater insight into the nature of social agreements about the use of acoustic media in the context of repressive power regimes.

The present article attempts to show that the relationship between the audio media and the listening contexts of totalitarianism should be treated as contingent. Based on an analysis of early film sound projects in the Soviet Union, it intends to demonstrate how, on the one hand, electro-acoustic media were used to reconfigure traditional soundscapes and how, on the other hand, local (social, mytho-religious) semantics of sound entered into the constitution of such electro-acoustic soundscapes.

\section{The Totality of Voice in the Eastern Christian Interpretation of Sound}

The human voice constitutes a basic two-channeled identification system, which allows the establishing of a correlation between the production and the reception of sounds: I hear myself, therefore I produce sounds; I produce sounds, therefore I hear them. The projection of this production-reception schema onto the environment accounts for the "channel purism" [Kanalpurismus] of many religious systems. To this day, the differentiation between sounds whose source is human and all other sounds remains essential to such religions as Islam and Eastern Christianity. Thus, for instance, in Russian churches the use of musical instruments is not allowed for the reason that instruments are unable to pray. Protestantism knows of a similar dilemma, though it observes this difference less rigorously.

Since the Early Middle Ages, Catholic priests (similarly to Russian clergymen and Muslim muezzins, or callers to prayer), were expected to have special capabilities in the interpretation of sound. ${ }^{6}$ But only in Western regions did musicians of the sixteenth and seventeenth century supersede religious interpreters who conveyed sacred messages using their voice. In the cultural contexts of both Western and Eastern Christianity, collective acoustic signal-calls stood in a relationship of

$6 \mid$ See: Murray R. Schafer (1999: 215): "Throughout history the range of the human voice has provided an important module in determining the grouping of human settlements. For instance, it conditioned the 'long' farm of early North American settlers, where the houses were placed within shouting distance of one another in case of surprise attack, and the fields ran back from them in a narrow strip". 
reference to the human voice for many centuries. ${ }^{7}$ As late as in 1737 , a church intendant in the Bourbonnais (according to the account of Lucien Febvre) had the bells of his city lowered and flogged by the hangman in medieval fashion, because they had dared to ring out against the royal guard (Febvre 1942: 322). In Russia, church bells were ensouled and treated as living beings much longer and more consistently than in the West. As a result, they were punished for conveying heretical messages by being thrown to the ground, flogged and carried off to Siberia after having their loop (ear in Russian) beaten off and their clapper (tongue in Russian) torn out. ${ }^{8}$ In places where complex social ties emerged more slowly, and where the writing-based learning process in the realm of acoustics did not occur linearly, the animistic interpretation of sound survived longer than in Western Europe. Even in the twenty-first century, the Russian church still practices customs in which un-enlivened church bells receive names and are mourned in memorial services. In 2002, for instance, the name of incumbent Russian president Vladimir Putin was engraved on the bells of the Holy Trinity-St. Sergius Monastery in Zagorsk, one of Russia's most important churches.

When the acoustic community acknowledges the arbitrary nature of sound symbols, it is reflected in national policy regarding both unenlivened and enlivened sound objects. Political power relies on the collective conviction that sound symbols lose their magical power when the sacred source of sound is exchanged or replaced by another source.

7 | Claude-Levi-Strauss reconstructed the prototypical, symmetrically arranged model of sound perception by analyzing the sender-recipient schemata found in mythology: "In the myths mentioned so far, the protagonists are receivers of noise; in other contexts, they turn into producers of noise" (Levi-Strauss 1976: 211).

$8 \mid$ Russian history tells of numerous bells that were "corporally" executed in this manner. The first of these is the bell of the Novgorod veche (people's assembly), which was dismounted, "arrested" and carried off to Moscow in 1478 by order of Ivan III. Another famous story concerns a bell from Uglich that was flogged with the knout in 1593 and taken to Tobolsk. The bell was said to have heralded bad news about the murder of Tsarevich Dmitrii. As punishment, the people threw the bell to the ground from the belfry, tore out its clapper, beat loose the loop of the bell and publically struck it twelve times with the knout on the town's main square. Afterwards, the bell was locked into the Tobolsk prison. In the second half of the eighteenth century, the bell of the Moscow Kremlin was punished for similar reasons and in similar fashion. During the Moscow Plague Riot of 1771, a large number of people had gathered under the bells. When Empress Catharine II was unable to find the conspirators (i.e. those who had rung the bell), she ordered that the bell itself be punished. First the "tongue" (clapper) of the bell was removed. The bell then hung at the Kremlin without a clapper until 1803. Today it is located at the armory in Moscow (Raushenbakh 1985: 304ff; Bondarenko 1998: 499ff). 
This collectively shared belief can explain the particular status of original sound recordings in the Soviet Union of the 1930s. The struggle of the first Soviet sound engineers to depict the industrial sound environment in the format of original sound was based primarily on ideological rather than technical reasons. These, if not determined directly by it, had much in common with the religious beliefs of the Russian Orthodox Church.

In the 1930s, film theorists outside the Soviet Union were of very different opinions regarding the extent to which original sound recording was not only feasible, but also necessary for generating an authentic soundfilm effect. The pioneer of sound-film theory Béla Bálazs expressed skepticism about the viewer's ability to distinguish between original versus studio sound (1926) ${ }^{9}$ Christian Metz later took a similar position: "In principle, nothing distinguishes a shot heard in a film from a shot heard on the street". ${ }^{10}$ In complete opposition to this, Williams argued that, unlike studio sound, original sound transmitted the traces of the acoustic context of a recording: “'identical' sounds (voices, instruments) seem different in different acoustic environments" (Williams 1980: 53).

Modern sound recording techniques (Dolby) allow the capturing of the subtlest nuances of a soundscape. In this process, the volume of low sounds is raised while noise is strongly reduced. The nuances of the soundscape could therefore be imitated in the studio as well, by blending recordings and special sound effects created with a synthesizer. ${ }^{11}$ To this day, sound film can and must dispense with original sound recordings for two reasons. First, the ambient noise contained in every original sound recording is often perceived as distracting by viewers. Second, ambient noise is superfluous during playback because the eye's corrective function neutralizes its effect. While looking at a screen that shows a running horse, one will easily identify the rattling of nutshells with the sound of hooves. One of the paradoxes of sound recording consists of the fact that studio sound often seems more effective than original sound. In the United States, England and Germany, early sound film often managed without recordings of original sound. In fact, studio

9 | See: Bálazs 1926-1931: 161: "Sound is cannot be depicted [...]. Not the image of [actor's] voice but the voice itself is shown".

10 | See: Metz 1975: 158: "Rien ne distingue en principe un coup de feu entendu dans un film d'un coup de feu entendu dans la rue".

11 | See: Flückiger 2002: 73: "One could imagine techniques that would eliminate this difference [between original and recorded sound]. It is also conceivable that the physical properties of original sound and recorded sound could coincide completely". 
sound recordings were utilized much more consistently at the time than in today's film shootings. ${ }^{12}$

Soon after the first experimental sound films were introduced into Soviet culture, inventors of the first sound-film camera and formalisticallyminded film interpreters claimed that the nature and function of Soviet sound film were essentially different from its German and American prototypes. While the talkie and the musical were of primary significance in the West, the proletarian cinema of the Soviet Union instead specialized in reproducing the sound picture of the heroic industrial workday (Sokolov 1930: 59; Shorin 1941: 90ff; Andrievskii 1931: 21).

When pioneer of Soviet sound film Dziga Vertov (Denis Kaufman) composed the "Sound March" for his film The Donbass Symphony in 1929, he provided the recordings of his sound sources with attributes that revealed an animistic understanding of the sound environment. ${ }^{13}$ The director rarely invented such attributes himself, however, drawing them from current newspaper articles instead: ${ }^{14}$ "The furious sound of the church bell rings out with new force;" "Suddenly one hears the strange whimper of a flying cross;" "A cry of pure delight escapes the orchestra"; or "The knocking sounds of the billet being forged" (Vertov 1929-1930: 1-6). ${ }^{15}$

12 | In his journal from the early 1930s, the American film director Rouben Mamoulian admits that, due to high production costs, original sound was used only rarely in American cinema: "In Applause unfortunately the traffic noises had to be made on the set. It was pathetic, and it still is pathetic when I hear it. But for the subway scenes we got permission to shoot in the subway. Those sounds were authentically recorded. We also shot in Pennsylvania Station, and I did a scene on the top of a skyscraper by breaking the law" (Cameron 1980: 90).

13 | The acoustic connotations of the artistic name invented by Dennis Kaufman, the descendant of a Jewish family from Bialystok (Poland), speak for themselves. The first name "Dziga" was meant to suggest the noise of the film editing machine (dz...dz...dz...), while the name "Vertov" is derived from the Russian root "vert" (to turn).

14 | Vertov 1929-1931, 5. See the following excerpt from an article in the Red Army newspaper from April 12 ${ }^{\text {th }}, 1923$ : "Suddenly the booming sounds of the bells ring out in the club-house. [...] One can hear the hoarse bass voices of the priests, accompanied by a pitiful crowd of old religious women. 'Long live the Internationale, brothers'-one hears inside the clubhouse. [...] To the astonishment of the priests and the believers, this passionate and powerful song resounded from the bell tower: 'Not God, nor Tsar, nor hero.' Thus the komsomoltsy sing from the bell tower of the monastery. A few old women make the sign of the cross.-Are those perhaps angels singing?" (Anonymous 1923: 1).

15 | Vertov countered reproaches by his opponents that characterized the industrial noises in The Donbass Symphony as monotonous and boring with the argument that the sounds in his film are "not at all monotonous; they are unusual [...] the 
The attempt of totalitarian propaganda to exaggerate the collective belief in an animistic sound environment, and to replace Christian sound media with those of the Bolsheviks, implied an understanding of Bolshevism as a doctrine of enlightenment that filled an inanimate environment with spirit. Thus, the enervating sound of the factory siren came to replace the metallic ringing of the church bell. In 1923, professional musician Mikhail Gnesin, a 1914 graduate in composition from the St. Petersburg Conservatory, was the first to speak of "communist bells". He was later to become the founder of Soviet music criticism in the USSR. In the same year, another representative of the musical avant-garde, Arsenii Avraamov, composed an entire symphony using factory sirens. Two immense open-air events, in Baku (Azerbaijan) and Moscow, made use of the pipes of every factory, the foghorns of the entire Caspian navy, as well as two artillery divisions.

In light of the demystification of Christian sound media, optical sound recording increasingly acquired a significant function and quasireligious impact. Not surprisingly, the passing of a decree on church congregations in 1929, the drafting of the secret resolution "On the Regulation of the Church Bells" on December $6^{\text {th }}, 1929$, the subsequent dismantling of church bells, as well as the first Soviet attempts in the sphere of sound film (1929) all coincided. ${ }^{16}$ Workers' decisions about the prohibition of bell ringing were frequently made in movie theaters following screenings of antireligious propaganda films. ${ }^{17}$ In the course of implementing party decisions, church bells were thrown to the ground by the Soviet Militia (similarly to medieval times), after their clappers

industrial workers read these sounds as meaningful signs [smyslovye znaki]" (Vertov 1930-1931: 83). See also Vertov's answer to the criticism of the Kiev film factory administration: "A worker that has been employed in manufacturing for years will recognize the sound of any factory. When he hears the sounds produced by the power plant, he will know that it sounds like the plant in Donbass" (Vertov 1930-1931, 59).

16 | See the following excerpt from this resolution: "The bell ringing practiced by the priests throughout the district contradicts the principle of the separation of church and state insofar as it infringes on the rights of the broad non-religious masses, prevents work and disturbs the workers in their free time. Under these circumstances, and based on requests stemming from the broad working masses (whose intellectual needs have increased in recent times), our administration must take highly restrictive and prohibitive measures regarding the ringing of church bells" (NKVD: Ob uregulirovanii kolokol'nogo zvonka).

17 | For instance, a gathering of audience members took place at the movie theater "Vostok" in Yoshkar-Ola (Mari El) on April 19 $9^{\text {th }}$, 1932. The viewers in the assembly are said to have demanded the legal prohibition of bell ringing. 
(tongues in Russian) had been removed. ${ }^{18}$ The devout reacted to the desecration of bells with ritual lament. ${ }^{19}$

The implementation of animistic standards of perception in original sound recording techniques presupposed an aesthetic principle that determined the nature of early Soviet documentary newsreels [ $d o k u$ mental'nye khroniki]. The camera crew in which the inventor of the first Soviet sound-film camera, Shorin, collaborated with Vertov, often used the single portable camera available at the time to record the voices of both birds and Soviet party functionaries in a same session. In his memoirs, Shorin liked to compare sound recording to a pre-modern form of hunting, using the ambiguous verb "to capture" to describe two distinct practices ("capturing with a trap" and "capturing with the microphone").

The second of the two accessible cameras that enabled original sound recording in nature was placed at the disposal of the Department of Documentary Film by the Shorin-Vertov team. Immediately thereafter, the state commissioned the Moscow film director Erofeev to produce original sound recordings in the Pamir Mountains. From a practical point of view, the goal of the laborious expedition into a region with "no electricity and no technical assistance" was difficult to comprehend (Shorin 1941: 91). It was clear that the entire range of supposed mountain sounds

18 | See the report of a clergyman who witnessed the dismounting of bells: "On the evening of April 19 [1935], a brigade of workers appeared. This time the watchman had the keys to the temple. He handed them over and the workers began to dismount the bells. But because it soon got dark the workers merely managed to take down the clapper of the large bell and to throw it to the ground. At night, the community spokesman convinced the men to return the clapper to the belfry, which they did. [...] Early in the morning came a group of four workers who had thrown down the clapper the night before. When they discovered that the large bell's clapper had been returned to its initial place, they began removing all of the bells, beginning with the smaller ones. At around this time, about fifty women gathered next to the belfry, protesting and crying very loudly, which did not help at first. But eventually the workers stopped and simply dropped their tools. They descended from the belfry and at the exit encountered a group of women that were crying loudly and reviling the workers as vampires. After that, the workers marched off to the village soviet, where they phoned to request Militia troops. Later, two armed militiamen arrived on horse and threatened the women with violence and the use of weapons" (Damaskin 2002: 167-183).

19 | See the following eyewitness report (Voronezh district): "The toppled bells were mourned by the peasant women like the deceased. Led by members of State security and a delegate of the Communist Party, a group of peasants arrived from Voronezh and went up the bell tower. When the women from the village noticed that the drunk peasants were preparing something on the tower, and were trying to lower and throw down the church bells, they began to wail even more loudly, as during an attack of the Tatars" (Annenkov 1990: 160). 
could be recorded in a studio or, at most, in a Moscow suburb. The Soviet state nevertheless insisted on original sound recordings. This approach had the ideological objective of opening the ears of the masses and of completely sensitizing societal perception to the infiltration of latent messages from the natural landscape.

\section{Dissolving the Boundary Between the Sonic Weapon and Sound Aesthetics}

Soviet experiments with audio media reveal a scientific culture whose ideological platform was based on an enlightenment faith of Eastern Christian provenance that had been equipped with technological attributes and symbols. Such a scientific culture exhibits, on the one hand, a continued tendency toward its dedifferentiation from religion, art and politics. On the other hand, it demonstrates a certain degree of reflexive scientification (see: Kozulin 1984; Weiner 1999; Berstejn 2001; Busky 2002; Andrews 2003). This scientification creates conditions under which societal introspection begins to regard science not as a source of solutions, but as a source of scientific problems. According to Beck (1986), this leads to the de-monopolization of scientific knowledge claims: science becomes more and more necessary, but at the same time less and less sufficient for the socially binding definition of truth.

With some reservations, one can argue that the concept of a psychotronic weapon, which was already coined by the scientistic utopias of the 1920s, influenced later Soviet experiments in the field of radiohypnosis. The 1920s through 1930s witnessed the large-scale Soviet experiments of Lazarev, Bekhterev and Kazhinskii, who studied brain waves that were assumed to be capable of transmitting both thoughts and transcendental messages over long distances. For proletarian theatre performances, devices such as "Fonofot" were constructed (1924). These can be considered the prototypes of later technologies of behavior control whose objective was to manipulate the aesthetic impressions of the audience by psycho-physiological means. ${ }^{20}$

As in the case of many technological innovations, the motivation for research in the sphere of sound-wave radiation in the 1930s through the 1940s was based on military interests. Accordingly, public scientific

20 ( See: Zapiska izobretatelia instrumenta Fonofot (1924). See about psychotronic [non lethal] weapons: Defense News 1993, Defense Electronics 1995; Alexander 1995; Smirnov/Beznosiuk/Zhuravlev 1995. 
disputes had first to determine which electro-technical inventions fell into the category of entertainment and which were to be classified as weapons. The scientific experiments of the late 1920s in the sphere of entertainment focused primarily on analyzing sonic waves 1) whose frequency fell below the threshold of sensitivity (infrasound) or above this threshold (ultrasound) and 2) whose intensity remained below the threshold of audibility (10 dB-breathing) or ranged above the acoustic threshold of pain (130 dB-an aircraft engine).

Even before the invention of optical sound recording, Soviet physicists and artists alike anticipated the emergence of a medium that would erase the boundary between aesthetics and physiology. At the time, sonic weapons were the focus of scientific studies in both the realm of theater arts and the military sector. In 1928, the same year in which sound film appeared, the Red Army General Headquarters distributed a secret informational brochure about German and French military experiments with sound waves for the purpose of destroying the enemy both mentally and physically. ${ }^{21}$

While early experiments in the field of optical sound recording were

21 | The original text of the manual reads as follows: "Lately we are receiving information about experiments aiming at the solution of new tactical goals. These concern the effect of invisible waves over a long distance. The concrete question is not the impact of electricity but the impact of sound waves, or more preciselythe development of a device that generates certain sound waves, which are barely audible to the human ear. The data at our disposal allow us to conclude that such a device has already been developed in France. It produces ultrasound waves that are transmitted in the form of a beam of rays. The effect of these waves on the nervous system is very strong. In large crowds [...] such waves trigger the urge to flee. According to the information we have received, the operating principle of this device is based on a commonly known nervous reaction that can be produced in anyone. This reaction is caused when piercing sounds, such the scraping of a piece of metal on a smooth surface, are heard at close distance. Whoever hears such a sound has goosebumps and is forced to grind his teeth. These are barely audible sounds. But based on their extremely sharp effect they are almost equal to ultrasound. If the oscillation frequency exceeds 50000 per second, one can no longer hear the whistling sounds. However, a far-reaching effect on the nervous system is immediately noticeable. We have no technical specifications about the structure of the device. But we are receiving information (from Germany as well) on how the idea of such a device is to be realized. The Germans are likewise conducting experiments that aim to employ ultrasound waves in signaling systems. The descriptions of these experiments indicate that [...] ultrasound waves of low intensity do not cause any damage. But if the intensity of the waves increases, their effect on the skin can cause agonizing pain. Sonic generators of higher capacity could also be used as a military weapon" ("Voennoe ispol'zovanie noveishikh dostizhenii tekhniki" ["The Military Use of the Newest Achievements of Technology" 1928]). 
still being conducted in the Soviet Union, the effect of high-frequency sound waves was openly discussed as a boundary problem of warfare and musical aesthetics. The Soviet musical avant-garde made a significant contribution to experiments on the military use of sound waves, for instance. The name of the engineer Lev Termen (Leo Theremin) is associated not only with the invention of the Termenvox (an electronic musical instrument that can be played without physical contact). More importantly, Termen was famous in his time as a developer of signaling and eavesdropping systems. For many years, the KGB used his Buran device to intercept the conversations of foreign embassy workers. ${ }^{22}$

As the sound engineer for the first Soviet sound film, The Five Year Plan (Plan for Great Works, 1929), the composer Arsenii Avraamov worked with the "oscillation formula of the membrana basilaris, the acoustic organ responsible for the perception of music". Avraamov was of the opinion that "the composer who applied such a formula could literally deafen the listener". ${ }^{23}$ He believed that the impact of Dziga Vertov's Donbass Symphony could have been much more striking if the sound of the film had been produced by means of electro-acoustic synthesis, instead of using original sound recordings (Avraamov 1939: 316). Similar to the military studies cited above, the composer was primarily concerned with the piercing gliding sounds of the upper frequency range (beginning at circa 3,000 Hz). Beyond the acoustic effect, such a "differential music" was supposed to cause the body to tremble and the facial muscles to contract. $^{24}$

Whereas the first American sound film studio originated in the con-

22 | Over many years, Leo Theremin worked for the KGB and Soviet intelligence. In 1926, he developed an experimental device with a wireless connection that served as a project for the first television set. See the following excerpt from an interrogation of Termen, who was later arrested as a "spy": "I worked on developing a new apparatus that was intended to be used for eavesdropping on the personnel of foreign embassies inside their rooms. The device was aimed at the windowpanes. Based on the recorded oscillations, one could determine what was being discussed in the room" (Anfilov 1962: 192ff; Kaplunova 1988: 2).

23 | See: Avraamov 1916: 85: "Only few people realize that the physiological structure of the ear requires careful handling of the notes of the fourth octave [...]. This is of enormous practical significance, because [...] having switched to the register of e4-c4, the composer [can] literally deafen his listener [...]".

24 | See: Avraamov 1939: 319: "This 'differential music' (we have called it thus by analogy with differential analysis in mathematics, since differential analysis has introduced the concept of infinitely small numbers) could solve the problems science is currently facing [...] It possesses such resources as we used to merely 'suspect.' [...] We know that 'glissando' [gliding sound, D. Z.] is a highly effective tool [...]. Nature itself has invented it: the howl of the jackals, the whistling of wind and storm, 
text of silent film production in Hollywood and the first German sound film studio in the context of silent film production in Babelsberg, Soviet sound film was subordinated to the Radio Institute from the very beginning; as a result, its production studios were located at the Central Telegraph Building. Even though pre-revolutionary Russian silent film studios such as the Mosfilm studio established around 1924 were also available for the development of sound film in the USSR, the Soviet administration chose a different option. ${ }^{25}$ Their decision was based on the theory of so-called electro-acoustic telepathy, in which recently discovered cerebral radiations were over-generalized as a type of universal energy. Around 1920, Petr Lazarev had first observed brain-generated electromagnetic waves with a frequency range of 10 to $50 \mathrm{~Hz}$. From these, the scientist deduced the human ability to transmit thoughts across distances in the form of electromagnetic waves (Lazarev 1920: 6). In 1924, Bernard Kazhinskii conducted an experiment in the applied laboratory for zoological psychology that studied the transmission of telepathic commands from humans to dogs (Kazhinskii 1928). A hypnotized dog was supposed to jump onto a chair in response to the unspoken command of the scientist. Although the results of the study remained inconclusive, the idea of cerebral radiation inspired broad layers of the intelligentsia to a new conceptualization of the Soviet public.

It is highly indicative that the majority of sound engineers who actively developed early Soviet sound film were university-educated neuropsychologists. Dziga Vertov and Abram Room studied this subject at the Institute of Neuropsychology in St. Petersburg. ${ }^{26}$ The terms "RadioEye" 27 and "Radio-Ear" 28 , which Vertov used to define the functions of

and the sighing, groaning and squealing of man are all examples of glissando in nature".

25 | In all, three silent film factories existed in Moscow. The main film studio of Khanzhonkov was renamed the "First Factory of State Cinema" after the Revolution. Already in 1924, the film studio "Mosfilm" was opened by combining the First and Third Film Factories.

26 | In the years 1914 to 1917 , Abram Room studied at the St. Petersburg Institute of Neuropsychology. From 1917 to 1922, he continued his scientific career at the medical faculty of Saratov State University, while simultaneously working as an instructor at the Theatre Workshop.

27 | See: Vertov 1924: 118: "Several years ago we posed the question of the radioukho ('Radio-Ear', D.Z.) and radioglaz ('Radio-Eye', D. Z.) and the invention of sound film has preempted this question". See: Zakharine 2009a; Zakharine 2009b.

28| See: Vertov 1966: 55: "We will state it once more: the eye and the ear. The ear cannot see; the eye cannot listen. The division of functions". Vertov most likely adopted the concept of the division of functions of eye and ear from Helmholtz. Helmholtz developed the "concept of non-overlapping qualitative spheres" [sich nicht 
Soviet sound media, alluded to Beliaev's novel The Radio-Brain, published in excerpts in the Red Newspaper from 1926 to 1929 (see: Beliaev 1928: Chapter 17). The novel told of a self-controlled psychotronic apparatus (a "small screen [...] for reading minds") that learned to program the behavior of Soviet citizens. Through the use of direct and indirect citations, the novel popularized the ideas of Lazarev and Kazhinskii, who interpreted the effect of cerebral radiation in terms of electronic telepathy. ${ }^{29}$

Influenced by new publications in the sphere of electro-acoustic telepathy, film theorists such as Sergei Eizenshtein, who had initially been critical about the future of the talkie, revised their montage theories (1929). According to Eizenshtein's confession, this revision took place "in unison with what was taking place in acoustics". Montage technique would henceforth contain "a physiological component [...] just like music whose effects are caused by the overtones". In the work of Eizenshtein, the new concept of overtone montage [obertonnyi montazh] implied the broadening of sensory stimuli beyond the limits of the screen. Film became a medium that was meant to put the viewer into uncontrollable states. Thus, according to Eizenshtein's account, the film The General Line (1929) was created based on "the collision and combination of individual stimuli $[\ldots]$ ". When the director was shooting scenes of mowing peasants, he moved the camera slightly from side to side. Afterwards he laughed "with all his soul" as he "secretly observed the audience in the movie theater". Sitting in their seats, they were rocking from side to side, at first slowly, then "faster and faster, as the images on the screen became shorter and shorter" (Eizenshtein 1929: 504). ${ }^{30}$

Not long before the appearance of the first Soviet sound film in 1929, the Association of Workers of Revolutionary Cinema (ARRK) was engaged in discussing of Stalin's directive on the state of Soviet film. This directive intended to "replace" the traditional vodka business as a source of na-

überschneidende Qualitätskreise] which enclose the processing of stimuli: "The same ethereal vibrations that appear as light to the eye are felt as warmth by the skin. The same aerial vibrations that the skin perceives as a light touch are perceived as sound by the ear" (Helmholtz 1959: 16).

29 | See the following excerpt from the novel: "YYes', Takh replied quietly. 'I've already said that I found a material that would help receive these waves. I have defined these waves as 'C-waves' or ' $\mathrm{C}$-rays' (from the word cerebrum, Latin for 'brain'). [...] C-waves of infinitely short length are reminiscent of the $\mathrm{x}$-rays that serve to illuminate the screen"' (Beliaev 1928: Chapter 17).

30 | The question to what extent Eizenshtein's concept of overtone montage could also be understood as a parody of mainstream discourse can not be discussed in any detail in this article. 
tional tax revenues "with radio and film" (CPSU 1928: 60). ${ }^{31}$ The Soviet film industry was faced with the task of eliminating, in short order, the disparity between tax revenues stemming from the sale of alcohol and from film distribution. In accordance with Lemberg's plan, which was supported by the workers' assembly, "film was to replace vodka". Among the most significant arguments in favor of this replacement strategy were the results of surveys conducted in the Kharkov region. These polls documented a "large interest among the population" in film screenings, which the people referred to as "misty pictures" [tumannye kartiny].

In the debates led by the ARRK in 1929 and 1930, the physio-aesthetic effect of sound film was understood in connection with Ivan Pavlov's theory of reflexes. ${ }^{32}$ The film director Abram Room advanced the argument that sound film would be ideally suited to the implementation of reflexology in cinematic practice. In his view, film directors had to capture the nerve reflexes of the actors in order to meet the new demands of the sound camera as a cognitive medium. Room based his ideas on the parallel depiction of animal and human reflexes in a film by Pudovkin that reconstructed and demonstrated the procedure of Pavlov's experiments with dogs. 33

The comparison between animal and human reflexes became the topic of scientific news from various fields of research shortly before the emergence of sound film. For instance, the first part of the documentary film The Achievements of Soviet Science (1929), entitled Experience with the Acclimatization of Monkeys at the Sukhumi Zoo, showed a Sacred Baboon that had been born at the zoo. The second part of the film (The Great Mute Begins to Talk) then introduced Tager and Shorin, the in-

31 | Stalin's directive took up an idea posited by Trotsky: "The state can integrate [film] into the spheres of leisure and national education more and more by opposing cinema to alcohol and turning film into its own source of income" (Trotskii 1927: 23). In a lecture from March $7^{\text {th }}, 1929$ entitled "Vodka and Cinema", Lemberg (a member of the ARRK) expressed the problem of the disproportionate distribution of income as follows: "Whereas the national income from film production comes to no more than 20 million rubles, tax revenues from Tsentrospirt in the years 1925-1926 amounted to 370 million" (Lemberg 1929: 3).

32 | In the years 1924-1925, Room designed the Course of Lectures on Reflexology for the audience of the Meyerhold Theatre.

33 | See: Room 1929: 16: "Just as in the case of the dog that salivates after seeing a picture of food, light is considered a stimulus in the case of the actor [...]. Such great men as Bekhterev and Pavlov relied on Darwin in their research. They did not work with actors; they worked with animals. [Therefore] we need a psychological laboratory for the purely cinematographic study of man; we should study the reflexes of film actors". 
ventors of the first Soviet sound film cameras. ${ }^{34}$ Many of the audience members knew the goal of breeding apes at the Georgian zoo from overt newspaper publications. Based on a theory advanced by the veterinarian Dr. Ivanov, scientists planned to transplant the male reproductive glands of apes into the bodies of the old Bolsheviks in order to retard the aging process. ${ }^{35}$ The images of sound film cameras alluded to another scientific miracle, which consisted of the "ensouling" of the silent film camera. Consequently, it remained for the audience to conceive of sound film as a medium that could infinitely extend the human capacity for cognition. ${ }^{36}$ By analogy, apes were presented as the source of the animalistic sexual virility of the future man.

In conclusion, it can be argued that the consolidation of the concepts of totalitarian power and of the total medium in the Soviet Union of the 1930s occurred in two ways. The first was the hermeneutic approach, which concerned the interpretation of the sound environment. The latter allowed archaic animistic interpretations of sound, which had been partially predetermined by Eastern Christian church doctrine, to resurface in the sound symbols, used by radio and sound film compositions. Consequently, the idea of church bells as living beings was projected onto the factory siren. The second approach was a scientism that promoted the dedifferentiation of physics and religion. Inspired by inventions in the realms of ultrasound, cerebral radiation and the study of reflexes, scientifically trained sound engineers theorized acoustic sound media as an alternative to psychoactive substances. Such theories implied the dissolution of the boundary between aesthetics and physiology on the one hand and between the public and the individual on the other hand. The two approaches indicated here allow for the conclusion that the electro-acoustic types of media that are viewed as playing a decisive role in Soviet totalitarianism are, in fact, in continuity with the interpretive schemata established by local cultural contexts. So-

34 | The film is located at the Russian State Documentary Film and Photo Archive (Code 1-2087).

35 | See: Shishkin 2003: 17ff. The book gives a detailed account of Soviet biologists' experiments with transplanting ape glands. Following a series of failed experiments, both Stalin and Zinov'ev lost confidence in the veterinarian Ivanov, who had planned the rejuvenation of the Bolshevik elites. The doctor was arrested.

36 | In the discussion that occurred following Room's lecture at the Association of Revolutionary Film-Workers in 1929, one worker (Kirshon) suggested combining the innovative theory of reflexes with the initial experiences in the field of scoring silent films: "The formation of reflexes must be taken into consideration, and here we see that German filmmakers do just that, by using music to evoke specific moods and states" (Room 1929: 30). 
viet audio media stood in the service of totalitarian power only insofar as they invoked the traditional sound symbols of Old Russia and relied on the customary cooperation between expert networks in both the natural sciences and the humanities.

\section{References}

Alexander, J. B. 1995. Non-lethal Weapons and the Future of War. LA-UR 95-699. Invited presentation to the Harvard-MIT Seminar on the Future of War (March $\left.9^{\text {th }}, 1995\right)$. John M. Olin Institute for Strategic Studies, Harvard University Center for International Affairs.

Andrievskii, A. 1931. Postroenie tonfil'ma. Leningrad: GIKhL.

Andrews, J. 2003. Science for the Masses. The Bolshevik State, Public

Science and the Popular Imagination in Soviet Russia, 1917-1934. Texas: A\&M University Press.

Anfilov, G. 1962. Fizika i muzyka. Moscow: Detgiz.

Annenkov, I. [1929] 1990. Kulatskie deti. Moscow.

Anonymous. 1923. Red Army newspaper [Krasnaia armiia] (April 12 ${ }^{\text {th }}$ ): 1 . Anonymous. 1929. Assotsiatsiia rabotnikov revoliutsionnogo kinematografa. Russian State Archive of Literature and Art [Rossiiskii Gosudarstvennyi Arkhiv literatury i iskusstva, RGALI]: fond 2494, opis 1 , delo 219.

Aristotle. 1984 The Politics. Translated and with an Introduction, Notes and Glossary by Carnes Lord. Chicago: University Of Chicago Press.

Avraamov, A. 1916. Griadushchaia muzykal'naia nauka i novaia era istorii muzyki. Muzykal'nyi sovremennik 6: 81-85.

Avraamov, A. [1939] 2001. Sinteticheskaia muzyka. Kinovedcheskie zapiski 53: 324-332.

Balázs, B. 1926-1931. Schriften zum Film. Berlin: Henschel.

Barnier, M. 2002. En route vers le parlant. Histoire d'une évolution technologique, économique et esthétique du cinéma (1926-1934). Liège: Céfal.

Beck, U. 1986. Risikogesellschaft. Aufdem Weg in eine andere Moderne. Frankfurt am Main: Suhrkamp.

Beliaev. 1928. Radio-mozg. Moscow.

Berstejn, V. 2001. The Perversion of Knowledge. The True Story of Soviet Science. Cambridge: Westview.

Bondarenko, A. 1998. Moskovskie kolokola XVII veka. Moscow. 
Burke, P. 1992. The Fabrication of Louis XIV. New Haven: Yale University Press.

Busky, D. 2002. Communism in History and Theory. From Utopian Socialism to the Fall of the Soviet Union. Westport: Praeger Publishers.

Cameron, E. 1980. Sound and the Cinema. The Coming of Sound to American Film. Pleasantville: Redgrave.

Chion, M. 1990. L'Audio-vision. Son et image au cinéma. Paris: Nathan. Crafton, D. 1997. The Talkies. American Cinema's Transition to Sound 1926-1931. New York: Charles Scribner's Sons.

Damaskin [Orlovskii], I. 2002. Mucheniki, ispovedniki i podvizhniki blagochestiia Russkoi Pravoslavnoi Tserkvi XX stoletiia. Volume 6. Tver.

Defense Electronics (editor). 1995. Russians Continue Work on Sophisticated Acoustic Weaponry. Defense Electronics 26 (March): 12.

Defense News (editor). 1993. U.S. Explores Mind-Control Technology. Defense News 4 (11-17 Jan.): 29.

Eizenshtein, S. [1929] 2000. Chetvertoe izmerenie v kino. In Montazh, 503-516. Moscow.

Enders, B. 1999. Global Village, Global Brain, Global Music. Osnabrück: Electronic.

Epping-Jäger, C. 2003. “Eine einzige jubelnde Stimme”. Zur Etablierung des Dispositivs Laut/Sprecher in der politischen Kommunikation des Nationalsozialismus. In Medien/Stimmen, edited by C. EppingJäger and E. Linz, 100-123. Köln: DuMont.

Epping-Jäger, C. 2006. Stimmgewalt. Die NSDAP als Rednerpartei. In Stimme. Annäherung an ein Phänomen, edited by D. Kolesch and S. Krämer, 147-172. Frankfurt am Main. Suhrkamp.

Eyman, S. 1997. The Speed of Sound. Hollywood and the Talkie Revolution 1926-1930. New York: Simon and Schuster.

Febvre, L. 1942. Le problème de l'incroyance au 16e siècle. Paris: A. Michel.

Fischer, L. 1977-1978. Enthusiasm. From Kino-Eye to Radio-Eye. Film Quarterly 31 (2): 25-34.

Flückiger, B. 2002. Sound design. Die virtuelle Klangwelt des Films. Zürich: Schüren.

Gleason, A. 1995. Totalitarianism. The inner history of the Cold War. Oxford: Oxford University Press.

Helmholtz, H. 1959. Die Tatsachen in der Wahrnehmung. Zählen und Messen erkenntnistheoretisch betrachtet. Darmstadt: Wissenschaftl. Buchgesellschaft. 
Kaplunova, M. 1988. Voina i mir L'va Termena. Moskovskie novosti 10: 1-2.

Kazhinskii, B. 1928. Biologicheskaia radiosviaz’. Kiev.

Kozulin, A. 1984. Psychology in Utopia. Toward a Social History of Soviet Psychology. Cambridge: MIT Press.

Lazarev, P. 1920. O rabote nervnykh tsentrov s tochki zreniia ionnoi teorii vozbuzhdeniia. St. Petersburg.

Lemberg, E. 1929. Stenogramma obsuzhdeniia doklada Lemberga "Vodka i kino". Russian State Archive of Literature and Art [RGALI]: fond 2494, opis' 1, ed. khr. 227.

Lévi-Strauss, C. 1976. Der nackte Mensch. Mythologica IV. Frankfurt am Main: Suhrkamp.

Marszolek, I. 2005. Lautsprecher und leise Töne. Radio im Nationalsozialismus. In Hörstürze. Akustik und Gewalt im 20. Jahrhundert, edited by N. Gess, F. Schreiner and M. K. Schulz, 53-68. Würzburg: Königshausen \& Neumann

McLuhan, M. 1964. Understanding Media. London: Routledge.

McLuhan, M. 1968. Magische Kanäle [Understanding Media]. Düsseldorf: Econ.

Metz, C. 1975. Le Perçu et le nommé. In Essais sémiotiques. Paris: Klincksieck.

Raushenbakh, B. 1985. Kolokola. Istoriia i sovremennost'. Moscow.

Red Army General Headquarters. 1928. Voennoe ispol'zovanie noveishikh dostizhenii tekhniki. Russian Military Archive [RGWA]: fond 33776, opis' 1, ed. khr. 889.

Room, A. 1929. Stenogramma obsuzhdeniia doklada A. M. Rooma, Uchenie o refleksakh' 10 ianvaria 1929 goda. Russian State Archive of Literature and Art [RGALI]: fond 2494, opis' 1, ed. khr. 229.

Schafer, R. M. [1977] 1994. Soundscape. The Tuning of the World. New York: Destiny Books.

Shishkin, O. 2003. Krasnyi Frankenshtein. Sekretnye eksperimenty Kremlia. Moscow.

Shorin. 1941. Kak ekran stal govoriashchim. Moscow.

Smirnov, I., E. Beznosjuk and A. Zuravlev. 1995. Psychotechnologien. Computergestützte psychosemantische Analyse auf der Ebene des Unterbewusstseins [orig. Psichotechnologii. Kompjuternyj analiz i psichokorrekcija na neosoznavaemom urovne]. Moscow.

Sokolov, I. 1930. Postroenie pervogo zvukovogo fil'ma. Russian State Archive of Literature and Art [RGALI]: fond 2639, opis' 1, ed. khr. 59. Tager, P. 1929. Sushchnost' zvukovogo kino. Rabis 38: 1. 
Tager, P. 1937. Otryvok iz istorii sovetskogo zvukovogo kino. Russian State Archive of Literature and Art [RGALI]: fond 2690, opis' 1, ed. khr. 13.

Trotskii, L. 1927. Sochineniia. Volume 21. Moscow.

Vertov, D. 1929-1930. Tetrad' s planami ozvuchivaniia fil'ma "Simfoniia Donbasa”. Russian State Archive of Literature and Art [RGALI]: fond 2091, opis' 2, ed. khr. 240.

Vertov, D. 1930-1931. Materialy raboty Dzigi Vertova nad dokumental'nym fil'mom “Simfoniia Donbasa”. Russian State Archive of Literature and Art [RGALI]: fond 2091, opis' 2, ed. khr. 417.

Vertov, D. 1931. Radio-glaz. Russian State Archive of Literature and Art [RGALI]: fond 2091, opis' 2, ed. khr. 159.

Vertov, D. [1923] 1966. Kinoki. In Stat'i, dnevniki, zamysly, 55. Moscow.

Vertov, D. [1924] 1966. Rozhdenie kinoglaza. In Stat'i, dnevniki, zamysly, 73. Moscow.

Weiner, A. 1999. Nature, Nurture and Memory in a Socialist Utopia. The American Historical Review 104 (4): 1114-1155.

Williams, A. 1980. Is Sound Recording Like a Language? Yale French Studies 60: 51-66.

Zakharine, D. 2009a. Sound Film as a Sonic Weapon. The Early Experience of the Soviet Talkies [Tonfil'm kak zvukovoe oruzhie. Rannii opyt sovetskogo zvukovogo kino]. In Stumm oder vertont. Krisen und Neuanfänge in der Filmkunst um 1930, edited by D. Zakharine, 243-261. Munich.

Zakharine, D. 2009b. The Ideology of Sound Art [Ideologiia zvukopisi. Zvukovoi kadr v zerkale medial'noi antropologii]. In In Stumm oder vertont. Krisen und Neuanfänge in der Filmkunst um 1930, edited by D. Zakharine, 225-243. Munich.

Zapiska izobretatelia instrumenta Fonofot. 1924. Russian State Achive of Literature and Art [RGALI]: fond 963, opis' 2, ed. khr. 47. 